\title{
An Empirical Study on Role of Travel Start-Ups and Entrepreneurship in E-Tourism
}

\author{
Lalitha Krishnamurthy ${ }^{1}$, Arockia Rajasekar ${ }^{2}$, D. Raja Jebasingh ${ }^{3}$ \\ ${ }^{1}$ Department of Travel \& Tourism, Mount Carmel College, Bangalore, India \\ ${ }^{2}$ Department of Commerce, St. Joseph's College (Autonomous), Trichy, India \\ ${ }^{3}$ Department of Commerce, St. Joseph's College of Commerce (Autonomous), Bangalore, India \\ Email: klalitha04@gmail.com
}

How to cite this paper: Krishnamurthy, L., Rajasekar, A. and Jebasingh, D.R. (2019) An Empirical Study on Role of Travel Start-Ups and Entrepreneurship in E-Tourism. Journal of Service Science and Management, 12, 620-627.

https://doi.org/10.4236/jssm.2019.125042

Received: July 3, 2019

Accepted: August 12, 2019

Published: August 15, 2019

Copyright $\odot 2019$ by author(s) and Scientific Research Publishing Inc. This work is licensed under the Creative Commons Attribution International License (CC BY 4.0).

http://creativecommons.org/licenses/by/4.0/

\begin{abstract}
Purpose: Travel Start-ups and Entrepreneurs design web pages to promote niche products and operate a business through Information and Communication Technologies (ICT) enabled E-tourism. Methodology: 500 respondents were reached out for the survey. Descriptive statistics are applied to analyze the primary data collected from the respondents prevailing in Bangalore. Findings: Data analysis of Bengaluru city indicates that qualification and age play a vital role in the use of internet-driven technology. Travel Start-ups and Entrepreneurship caters to young generation travelers who prefer to pay little extra money to access the facilities operated through web page or Apps in a smartphone with the help of internet to enjoy niche tourism. Travel start-up and entrepreneurship process generates employment opportunities in the ever-growing travel and tourism industry and promotes niche tourism among young generations through OTP and App drove services. Originality/Values: Travel automation paved the way for E-commerce in retail tourism, and E-commerce promoted websites, online travel portals (OTP) and App driven M-commerce. This industry encourages intermediary services and provides ample scope for entrepreneurship and travel start-ups by operating various online portals and web portal to cater to niche tourism according to traveler's preference and choice.
\end{abstract}

\section{Keywords}

E-Tourism, Entrepreneurship, Travel Start-Up, Young Generation Niche Tourism

\section{Introduction}

Tourism sector creates direct, indirect, and induced employment. It produces a 
vast spectrum of employment from highly qualified and trained managers of star hotels to room boys, salesgirls, and artisans. With its faster growth, new horizons of employment open up for the youth of the developing countries. In India, tourism has become one of the major sectors of the economy, contributing to a large proportion of the National Income and generating huge employment opportunities. International tourist arrivals figures are forecasted to exceed 1.8 billion by 2030. This industry is the seventh-largest in India and second largest in the world and its consumption of the workforce is higher than any other industry. Tourism industry encourages the intermediary service sector, and this paves the way for the role of entrepreneurship [1].

Travel Consultants, Freelancers, Tourist Guides, Visa Facilitators, Tour Escorts, are some of the popular role of Entrepreneurship services in the Travel and Tourism industry. Travel Consultants and Freelancers serve their clientele with travel requirements by representing an established travel agency as its sub-agent and earn a commission. Tourist Guides job comes under the category of entrepreneurship who are trained and certified by the Ministry of Tourism. They work and earn temporarily based on tourist demand and arrivals. They provide information on tourist destination to the tourists. Visa facilitators are entrepreneurs who work to process visas for the clientele of travel agents who wish to outsource visa processing services. Tour Escorts are also entrepreneurs who are hired by tour operators to handle any crisis on tour operations.

The structure of the research article is as the conceptual content of the research area, existing theoretical work, and gap, an empirical model with descriptive statistics to arrive at the findings and conclusions. Primary data collected from 500 respondents residing in different locations of Bangalore, as shown in the above table. North region shows the highest with 26.4 percent; South region is 25.6 percent, East region is 24.8 percent and West region is 23.2 percent of respondents are respectively participating in booking online travel services.

The study is designed to analyze the usage of the technologically enabled application, user preferences, and factors influencing the travel and tourism industry with special reference to Bangalore urban. The work is an attempt to understand the level of technology adaptiveness among the users of the travel and tourism industry with the basic application of statistical tools.

\section{Conceptual Framework}

Travel agents are intermediaries who represent principal travel suppliers and serve the ultimate travelers. Travel agents provide travel-related information and ensure that passengers have a hassle-free memorable trip. This entire process is automated and dominated by OTPs and Apps. Travel automation paved the way for the growth of E-commerce in retail tourism. E-tourism refers to a phenomenon and research area in which the adoption of information and communication technology (ICT) by tourists and tourism businesses transforms the processes and value chains in the industry [2]. 


\section{Theoretical Background}

The current trend is to sell products and services through the internet for most of the service providers. Customer's purchase intention is dependent on their acceptance of online shopping's delivery channel. Shim et al. suggest that customers' attitudes towards online purchasing are dependent on transaction services, convenience, sensory experience, and merchandise [3]. Law and Leung identified product and pricing information, online booking facilities, and quick web page load time as determinants of customer satisfaction with online airline travel sites. Swedish Trade and Investment Council, Sweden encourages new business ideas to reach the market in the most digitally connected economy and provides an environment for new ideas [4]. Global Entrepreneurship Monitor defines entrepreneurship as "any attempt at new business or new venture creation, such as self-employment, a new business organization, or the expansion of an existing business, by an individual, a team of individuals, or an established business [5]. India is the third-largest start-up base nation with over 3100 start-ups. More than 800 start-ups are being initiated every year and project the presence of more than 11,500 start-ups by the year 2020 by the Start-up India program initiated by Government of India [6]. Hospitality and tourism websites have focused on the usability and accessibility of the business or organization's websites. The evaluation of website design has attracted many empirical studies [7]. Mobile technology has changed the tourists' experiences. Availability of mobile for $24 \times 7$ has eased the uncertainty and cultural barriers associated with traveling. Many mobile Apps and OTP websites exist for tourists are easily accessible on mobile. Mobile technologies, especially smartphones, are changing the tourist experience and the outlook of travel business [7]. Distribution technologies have gone through an evolution, but many systems such as GDS, CRS still co-exist even today. Online Travel Agencies (OTA) and OTP's are a type of intermediary that emerged from the wide-adoption of the Internet. It clearly indicates the growth of ICT enabled E-tourism [8].

\section{Research Model}

\subsection{Statement of the Problem}

The universe of the study comprises of travelers who avail online travel services and enjoy the comforts of App driven services that are available in ICT enabled E-tourism in Bengaluru City. Primary data collected from 500 respondents residing in different parts of Bangalore city. The questionnaire was designed to ascertain information of young generation people opting E-tourism services.

\subsection{Objectives of the Study}

Ascertain young customer's satisfaction towards online travel services.

Assess customer's preference to use App driven travel services.

Analyze factors that influence the use of technology in E-tourism. 


\subsection{Data Source}

The present study is empirical. Primary data was collected from respondents of Bengaluru city using questionnaire, and secondary data collected from Blogs, newsletters website browsing, and journals related to the area of study. Based on known objectives, a detailed questionnaire was drafted, and information was collected.

\subsection{Data Analysis}

Statistical tools are applied with the help of SPSS (Statistical Package for Social Sciences) to test the hypothesis applying descriptive statistics using Mean, Standard Deviation (SD), and percentage analysis.

\subsection{Limitations}

This study is limited to Bengaluru city; its results cannot apply to All India. Respondents viewpoint may change according to peer pressure. The study is limited to niche tourism only. A further role of tourism promotion, the quantum of revenue and employment generated can be studied.

\subsection{Further Research}

There is scope to dive deep into this area applying advanced research statistical methods like econometrics, emerging trends in technological advancements, and many more to explore.

\subsection{Sampling Technique}

The stratified random sampling method is adopted to arrive at the sample size of 500 respondents who belong to different age groups, probability sampling formula with a marginal error at 5 percent. The sample formula below has been adopted to arrive at the sample size.

$$
n=\frac{\frac{Z^{2} \cdot p(1-p)}{e^{2}}}{1+\left(\frac{Z^{2} \cdot p(1-p)}{e^{2} N}\right)},
$$

where $n=$ sample size, $z=$ confidence level ( $z=$ score value), $e=$ margin error, $N=$ population size, $p=$ population percent. Hence the sample size is equal to 385.

\section{Results}

Descriptive statistics applying Mean, standard deviation, and percentage analysis are the statistical tests performed to analyze the data. Table 1 shows that the mean value of the qualification is the highest at 2.70 . SD of the computer transaction is the least with 0.393 , which reflects that technology and the qualification plays a pivotal role in describing the better level of customer satisfaction while 
booking online travel services. The table indicates that young qualified respondents are more comfortable with computerized online transactions and App services, leading to the use of OTPs.

Table 2 states that 55.6 percent of the respondents are in the age group of 15 35 years, 33.8 percent are in the age group of $35-55$ years. 10.6 percent under age group of 55 - 65 years. It may notice that majority ( 55.6 percent) of the respondents were within the age group of 15 - 35 years. Those respondents in the group of 35 - 55 years were 33.8 percent while those in the age group of 55 - 65 years were found to be much less in number accounting to 10.6 percent of the total 500 respondents. It suggests that online services are comfortable with the young generation as compared to people who are aged 55 years and above.

Table 3 indicates that 233 respondents accounting to 46.6 percent of 500 respondents were graduates; 146 respondents accounting to 29.2 percent were Post Graduates; 78 respondents accounting to 15.6 percent were Professionals. Only 43 respondents accounting to 8.6 percent the lowest number were another category. It indicates that 457 respondents accounting to 91.4 percent educated with graduation and above.

Table 4 indicates the computer literacy levels of the 500 respondents who have participated in the survey. 440 respondents accounting to 88 percent of respondents are comfortable with computer transactions. Only 45 respondents accounting to 9 percent was not comfortable with computer transactions and 15 respondents accounting to 2 percent say that they are never comfortable with computer transactions.

Table 5 shows 409 respondents accounting to 81.8 percent use App driven services while 73 respondents accounting to 14.6 percent do not use App driven services and 18 respondents accounting to 3.6 percent have never used any App driven services.

Table 6 shows that 31.2 percent respondents use chatting App, 24 percent use E-commerce online services 23.8 percent use Google maps for navigation facilities, 15.2 percent use for banking facilities, 3.6 percent do not use Apps and a negligible 2.2 percent use for Foodservice. In the above data, collection E-commerce includes all online portals, including OTPs and App services.

Table 1. Table showing the profile of the respondents.

\begin{tabular}{ccc}
\hline Economic Profile & Mean & Std. Deviation \\
\hline Location & 2.83 & 1.439 \\
Age & 2.60 & 1.427 \\
Qualification & 2.70 & 0.933 \\
Computer transaction & 1.13 & 0.393 \\
APP services & 1.22 & 0.490 \\
\hline
\end{tabular}

Source: Computed from primary data. 
Table 2. Age of the respondents.

\begin{tabular}{ccc}
\hline Age & Frequency & Percent \\
\hline $15-35$ yrs & 278 & 55.6 \\
$35-55$ yrs & 169 & 33.8 \\
$55-65$ yrs & 53 & 10.6 \\
Total & 500 & 100.0 \\
\hline
\end{tabular}

Source: Computed from primary data.

Table 3. Educational qualification of the respondents.

\begin{tabular}{ccc}
\hline Qualification & Frequency & Percent \\
\hline Graduation & 233 & 46.6 \\
Post-Graduation & 146 & 29.2 \\
Professional & 78 & 15.6 \\
Others & 43 & 8.6 \\
Total & 500 & 100.0 \\
\hline
\end{tabular}

Source: Computed from primary data.

Table 4. Title computer literacy levels of the respondents.

\begin{tabular}{ccc}
\hline Computer Transaction & Frequency & Percent \\
\hline Yes & 440 & 88.0 \\
No & 45 & 9.0 \\
Never & 15 & 3.0 \\
Total & 500 & 100.0 \\
\hline
\end{tabular}

Source: Computed from primary data.

Table 5. Accessibility of App driven services by respondents.

\begin{tabular}{ccc}
\hline APP Services & Frequency & Percent \\
\hline Yes & 409 & 81.8 \\
No & 73 & 14.6 \\
Never & 18 & 3.6 \\
Total & 500 & 100.0 \\
\hline
\end{tabular}

Source: Computed from primary data.

\section{Findings}

The study based on data collection from 500 respondents with equal and fair distribution spread across the Bengaluru city. The statistical test confirms that young qualified respondents are more comfortable with OTP and App services. The younger generation is comfortable with online services, computer transactions, and App driven services like Chatting, E-commerce, and Google Maps, 
Table 6. Table displaying the usage of App by respondents.

\begin{tabular}{ccc}
\hline Usage of APP & Frequency & Percent \\
\hline None & 18 & 3.6 \\
Chatting & 156 & 31.2 \\
Banking & 76 & 15.2 \\
E-Commerce & 120 & 24.0 \\
Google Maps & 119 & 23.8 \\
Food & 11 & 2.2 \\
Total & 500 & 100.0 \\
\hline
\end{tabular}

Source: Computed from primary data.

leading to E-tourism. The study indicates that age and qualifications are the factors that influence the use of niche tourism through ICT enabled E-tourism that is promoted by travel start-ups and entrepreneurs. Both state and central governments provide financial assistance and encourage start-ups and entrepreneurship under its flagship program of Start-up India and Start-up Karnataka.

\section{Conclusion}

The tourism industry provides ample opportunities to both start-up and entrepreneurship. Young generations who are well qualified and tech-savvy are comfortable with ICT enabled E-tourism. The government of India promotes new avenues in travel start-ups and entrepreneurship by supporting financially.

\section{Conflicts of Interest}

The authors declare no conflicts of interest regarding the publication of this paper.

\section{References}

[1] Dayananda, K.C and Leelavathi, D.S. (2016) Tourism Development, Economic and Employment Growth in India. IOSR Journal of Humanities and Social Science (IOSR-JHSS), 21, 35-40.

[2] Buhalis, D. (2003) Etourism: Information Technologies for Strategic Tourism Management. Financial Times/Prentice Hall, Upper Saddle River.

[3] Bhayani, S. and Bavaria, R.D. (2018) An Empirical Study of Consumer Perception towards Online Travel Agency. Journal of Modern Management \& Entrepreneurship, 4, 125-134.

[4] Swedish Trade and Investment Council (2015) Potential for Swedish-Egyptian Cooperation on Entrepreneurship Inventing Tomorrow's World-Creating Jobs for the Future. The Swedish Trade and Investment Council.

https://books.google.co.in/books?id=yeZfDwAAQBAJ\&pg=PA540\&lpg=PA540\&dq =www.business_Sweden+Egypt+_entrepreneurship+study\&source=bl\&ots=M0sDC $\underline{\text { rV1op\&sig=ACfU3U2r0gzA1OwYYb4RAQzOjSq537_-ag\&hl=en\&sa=X\&ved=2ah }}$ UKE-

wiAwq7kqubjAhXLF3IKHeTkDQ0Q6AEwB3oECAkQAQ\#v=onepage\&q=www.bu 
siness_Sweden\%20Egypt\%20_entrepreneurship\%20study\&f=false

[5] Hattab, H. (2013) GEM Egypt 2012 Report. GEM-Global Entrepreneurship Monitor. http://www.gemconsortium.org/docs/3005/gem-egypt-2012-report

[6] Jacob, M. (2017) Entrepreneurships and Startup Programmes: Opportunities in Travel and Tourism. Atna: Journal of Tourism Studies, 12, 51-65.

[7] Law, R., Qi, S. and Buhalis, D. (2010) Progress in Tourism Management: A Review of Website Evaluation in Tourism Research. Tourism Management, 31, 297-313. https://doi.org/10.1016/j.tourman.2009.11.007

[8] Collins, G., Cobanoglu, C. and Malik, T. (2008) Hospitality Information Technology: Learning How to Use It. Kendall Hunt Publishing, Dubuque, IA. 